УДК 159.92

DOI https://doi.org/10.32838/2709-3093/2021.6/08

\title{
Заграй Л.Д.
}

Державний вищий навчальний заклад

«Прикарпатський національний університет імені Василя Стефаника»

\section{ЕМОЦІЙНИЙ ІНТЕЛЕКТ ЯК СКЛАДНИК ПРОФЕСІЙНОЇ КОМПЕТЕНТНОСТІ МЕНЕДЖЕРА}

\begin{abstract}
Мета статті - визначити ключові виміри емочійного інтелекту у структурі професійної компетентності менеджера (лідера). Завдання статті: здійснити теоретичний аналіз кониепиій емоиійного інтелекту у контексті професійної компетентності, зокрема менеджерів; визначити виміри емоційного інтелекту у структурі професійної компетентності менеджера. Визначено три групи досліджень емочійного інтелекту: ЕІ розглядають як здібність, яка пов'язана зі здатністю розуміти та контролювати емоиїі; ЕI вважають особистісною характеристикою; дослідники розглядають емоиійний інтелект як поєднання ичих моделей - змішані моделі. Емоиійний інтелект трактується як здатність обтрунтовано обмірковувати емочії та інформачію, пов 'язану з емочіями, $і$ використовувати емоції для підсилення мисленнєвого процесу. Окреслено моделі лідерства: трунтуються на иінностях конкурениії; трунтуються на цінностях взаємодії, впливу. Доведено актуальність емоційного інтелекту у структурі професійного профілю лідерства. Визначено чотири виміри здібностей: сприйняття емоцій, сприяння проиесам мислення, використання емоцій, розуміння емоцій та управління емоціями, які виконують функиію компетентностей людини щуодо емоційних переживань, проявів як своӥх, так і інших людей. Кожен із вимірів ЕI є умовою реалізації компонентів професійного профілю менеджерів. У профілі виділено три компоненти: иінності; базові атрибути; знання, компетенції. Характеристики компонента «иінності» пов 'язані із такими вимірами EI, як фасилітачія та розуміння емоцій; компонента «базові атрибути»фасилітація, управління, розуміння емоцій; компонента «знання і компетенції» - сприймання, управніння, розуміння емоцій, щзо дозволяє робити попередні припущення про емоиійний інтелект як інтегральну характеристику у професійному профілі менеджера, яка є необхідною умовою ефективної діяльності лідера.
\end{abstract}

Ключові слова: емочійний інтелект, компетентність, професійний профіль, менеджер, лідерство.

Постановка проблеми. В умовах сучасного менеджменту та лідерства все більшої актуальності набувають питання, які стосуються емоційного інтелекту як важливої здібності ефективного керівника. Наявності високих інтелектуальних здібностей та організаторських навичок не досить для ефективного менеджменту, а як наслідок цього - задоволення працівників та високих результатів організацій. Необхідні менеджери, які можуть розуміти власні емоції та інших людей, уміють контролювати їх у певному сенсі, які мають високі емоційні та соціальні можливості. $€$ дослідження, які доводять, що низька здатність до розуміння та контролю емоцій як своїх, так і інших людей призводить до численних проблем в організаціях, у неспроможності працівників до вирішення технологічних завдань, натомість високі показники емоційного інтелекту сприяють командоутворенню [15] та ефективній командній роботі, знижують рівень невпевненості та тривоги персоналу орга- нізації [6]. У численних дослідженнях розкрито зв'язок між емоційним інтелектом, особистістю, загальним інтелектом та ефективністю лідерства. Результати дослідження показали, що вищий емоційний інтелект у керівників-лідерів, які досягають більш високих результатів і сприймаються як ефективні лідери, а між емоційним інтелектом, особистістю, загальним інтелектом та ефективністю лідерства не визначено зв'язку [3]. 3 іншого боку, дослідження показали, що емоційний інтелект людини може бути ключовою детермінантою в ефективності управління [13].

Емоційний інтелект я розглядаю як конструкт, який складається 3 п'яти основних елементів, таких як: самосвідомість, саморегуляція, емпатія, мотивація та соціальні навички. Важливо 3'ясувати, наскільки вони важливі у структурі професійного профілю лідера. Мета статті - визначити ключові виміри емоційного інтелекту у структурі професійної компетентності 
менеджера (лідера). Завдання статті - здійснити теоретичний аналіз концепцій емоційного інтелекту у контексті професійної компетентності, зокрема менеджерів; визначити виміри емоційного інтелекту у структурі професійної компетентності менеджера.

Термін «емоційний інтелект» був уперше використаний у 1990 році Саловеєм та Майєром, які визначили емоційний інтелект як здатність розпізнавати, розуміти та управляти емоціями як власними, так і чужими. У міру розвитку досліджень усе більше учених починають займатися концепцією емоційного інтелекту. Натепер можна виділити три групи досліджень: емоційний інтелект розглядають як здібність (здатність ЕI), яка пов'язана зі здатністю розуміти та контролювати емоції; емоційний інтелект вважають особистісною характеристикою (риса ЕI); дослідники, які вважають емоційний інтелект поєднанням цих моделей і забезпечують більш широке тлумачення поняття, тому в цьому разі ми звертаємось до змішаних моделей [10]. У двох основних моделях ЕI відрізняється як концептуально, так і емпірично. Модель здібностей, здатностей спрямована на аналіз умов, які визначають способи вирішення різних ситуацій та управління емоціями. Модель емоційного інтелекту як риси більше пов'язана 3 особистістю та способом, який ми вибираємо для реагування у різних ситуаціях [5]. У змішаних моделях ЕI емоційний інтелект трактується не тільки як ментальна здібність індивіда, як здатність, в основі якої є механізми диференціації, розрізнення, розуміння, але й як особистісна характеристика. Дослідники К.В. Петрідес та Е. Фернхем довели зв'язок між аспектами прояву емоційного інтелекту (адаптивність, асертивність, усвідомлення емоцій, емоційна експресія, регулювання емоцій інших людей, емоційна саморегуляція, імпульсивність, міжособистісні взаємини, самооцінка, самомотивація, соціальна обізнаність, управління стресом, емпатія, щастя, оптимізм) та особистісними властивостями високого рівня розвитку (гнучкість і швидкість адаптації до нових умов життедіяльності; прямолінійність, відвертість, готовність стати на захист інших людей; здатність адекватно сприймати як власні емоції та почуття, так і оточуючих людей; уміння адекватно передавати свої почуття іншим людям у процесі спілкування з ними; здатність впливати на почуття інших людей; самоконтроль емоцій; непіддатливість імпульсам; доброзичливість і гармонія у стосунках; впевненість і відчуття себе успішною людиною; орієнтація на досягнення стійкого високого рівня самооцінки; високі соціальні здібності; стресостійкість; готовність до співчуття; відчуття радості й задоволення від життя; впевненість у завтрашньому дні).

Є вчені, які категорично заперечують доказовість концепції емоційного інтелекту, оскільки вони не вважають, що цей феномен має зв'язок з інтелектом, на їхню думку, не досить емпіричних доказів, що підтверджують існування окремих, відмінних факторів емоційного інтелекту від фактичного (когнітивного) інтелекту та логіки. У 2005 році E. Loke стверджує, що ще раніше Саловей і Майер (1990) представили концепцію соціального інтелекту, термін якого включав усі аспекти визначень емоційного інтелекту. Той факт, що визначення поняття постійно змінюється, створює проблеми в його наукових тлумаченнях. Далі E. Loke зазначає, що визначення поняття емоційного інтелекту настільки розширено, що складно об'єднати всі дані, що подаються до єдиної концепції (наприклад, можливість сприймати емоції інших не вимагає інтелекту, але залежить від бажання людини зосередитися на чомусь, здатність індивіда керувати своїми емоціями чи реакціями вимагає використання логіки та саморегуляціï). Е. Loke пропонує замінити концепцію емоційного інтелекту, не трактуючи його як здатність до самоаналізу чи як риси особистості [7].

Визначені три підходи у тлумаченні ЕI узагальнено у таблиці 1 [16].

Найбільш релевантною моделлю ЕI для аналізу його з точки зору складника профілю лідерства є нова модель [8], у якій ЕІ трактується як «здатність обгрунтовано обмірковувати емоції та інформацію, пов'язану 3 емоціями, і використовувати емоції для підсилення мисленнєвого процесу» [8, с. 296]. Більше того, ЕI розглядають як конструкцію, яка включає у себе здібності людини спостерігати за своїми і емоціями інших людей, розрізняти позитивні і негативні емоції та використовувати цю інформацію для регулювання мислення і дій [6]. Ці здібності передбачають виявлення емоційного змісту, сприяння мисленню, розуміння значень емоцій та управління емоціями [8]. Отже, модель має чотири групи (виміри) здібностей: сприйняття емоцій (із сімома здібностями), сприяння процесам мислення, використання емоцій (п'ять здібностей), розуміння емоцій (вісім здібностей) та управління емоціями (шість здібностей), які утворюють ієрархічну структуру, де найнижчий рівень відображає відносно прості здібності сприйняття і вираження емоцій, а найвищий рівень - усвідомлене регулювання емоцій. 


\begin{tabular}{|c|c|c|c|}
\hline & & & Таблиця 1 \\
\hline Майєр, Саловей & Бар-Он & Гоулмен & Купер, Савваф \\
\hline $\begin{array}{l}\text { Здібності до поєднання } \\
\text { почуттів та думок, } \\
\text { розуміння та аналізу } \\
\text { емоцій, контролю емоцій; } \\
\text { диференціації, оцінки і } \\
\text { адекватного вираження } \\
\text { емоції }\end{array}$ & $\begin{array}{l}\text { Визначені особистісні } \\
\text { характеристики та здібності: } \\
\text { індивідуальні, емоційні } \\
\text { і соціальні, які сприяють } \\
\text { успішній протидії тиску } \\
\text { навколишнього середовища }\end{array}$ & $\begin{array}{l}\text { Це здатність розуміти } \\
\text { власні та емоції інших } \\
\text { людей, керувати своїми } \\
\text { емоціями на індивідуаль- } \\
\text { ному рівні переживання } \\
\text { та на рівні стосунків } 3 \\
\text { іншими }\end{array}$ & $\begin{array}{l}\text { Здатність відчувати, розу- } \\
\text { міти та активно викорис- } \\
\text { товувати як джерело сили } \\
\text { власні емоції та швидке } \\
\text { сприйняття, розуміння, } \\
\text { енергію від стосунків } 3 \\
\text { іншими людьми }\end{array}$ \\
\hline \multicolumn{4}{|c|}{ Базові виміри } \\
\hline $\begin{array}{l}\text { 1. Сприйняття, оцінка та } \\
\text { вираження емоцій. } \\
\text { 2. Використання емоцій. } \\
\text { 3. Розуміння і судження } \\
\text { про емоції. } \\
\text { 4. Управління емоціями. }\end{array}$ & $\begin{array}{l}\text { 1. Міжособистісні навички: } \\
\text { емоційна самосвідомість; } \\
\text { упевненість; самоповага; } \\
\text { самоактуалізація; незалеж- } \\
\text { ність. } \\
\text { 2. Навички міжособистісного } \\
\text { спілкування: міжособистісні } \\
\text { відносини; соціальна відпо- } \\
\text { відальність; емпатія. } \\
\text { 3. Вимір адаптації: вирі- } \\
\text { шення проблеми; тестування } \\
\text { реальності; гнучкість. } \\
\text { 4. Подолання стресу: стій- } \\
\text { кість до стресу; контроль } \\
\text { імпульсів. } \\
\text { 5. Загальний настрій: щастя; } \\
\text { оптимізм. }\end{array}$ & $\begin{array}{l}\text { 1. Індивідуальна достат- } \\
\text { ність: самосвідомість; } \\
\text { саморегуляція; мотивація. } \\
\text { 2. Соціальна достатність: } \\
\text { емпатія; соціальні можли- } \\
\text { вості. }\end{array}$ & $\begin{array}{l}\text { 1. Розуміти емоції: } \\
\text { емоційна доброчесність, } \\
\text { справедливість; емоційна } \\
\text { енергія; емоційний від- } \\
\text { гук; практична інтуїція. } \\
\text { 2. Емоційна життєва } \\
\text { сила: базове існування; } \\
\text { коло довіри; конструк- } \\
\text { тивна невдячність; гнуч- } \\
\text { кість та оновлення. } \\
\text { 3. Емоційна глибина: } \\
\text { унікальний потенціал та } \\
\text { ціль; прихильність; жити } \\
\text { чесно; дія без дозволу. } \\
\text { 4. Емоційна алхімія: інту- } \\
\text { їтивний потік; ідеальне } \\
\text { варіювання часу; роз- } \\
\text { пізнавання можливості; } \\
\text { створення майбутнього. }\end{array}$ \\
\hline \multicolumn{4}{|c|}{ Тип моделі } \\
\hline Модель здібностей & Змішана модель & Змішана модель & Змішана модель \\
\hline
\end{tabular}

Перший вимір моделі ЕI сприйняття емоцій передбачає вміння: визначати оманливі або несправжні, невідверті, неправдиві емоційні прояви; вирізняти точні та неточні емоційні прояви; розуміти, як проявляються емоції залежно від контексту та культурних особливостей; точно виражати емоції у разі бажання; сприймати емоційний зміст у навколишньому середовищі, образотворчому мистецтві та музиці; сприймати емоції інших людей через їхні голосові сигнали, вираз обличчя, мову та поведінку; визначати емоції у власних фізичних станах, почуттях та думках.

Другий вимір ЕI сприяння процесам мислення, використання емоцій грунтується на здібностях: вибирати проблеми виходячи із того, як емоційний стан людини може сприяти їх вирішенню (когнітивній роботі); використовувати зміни настрою, щоб створити різні когнітивні перспективи; пріоритетне мислення, спрямовувати увагу відповідно до актуальних (теперішніх) переживань; генерувати емоції як засіб співвідношення 3 переживаннями іншої людини; створювати емоції як допоміжний засіб для судження та пам'яті.
Третій вимір ЕІ розуміння емоцій передбачає здібності: розпізнавати культурні відмінності в оцінці емоцій; розуміти, як може відчувати себе людина в майбутньому або за певних умов (афективне прогнозування); розпізнавати ймовірні переходи між емоціями, наприклад, від гніву до задоволення; розуміти складні та змішані емоції; розрізняти настрої та емоції; оцінювати ситуації, які можуть викликати відповідні емоції; визначати причини, значення та наслідки відповідних емоцій; позначати емоції та вирізняти взаємозв'язки між ними.

Четвертий вимір ЕI містить здібності: ефективно керувати емоціями інших людей для досягнення бажаного результату; ефективно керувати власними емоціями для досягнення бажаного результату; оцінювати стратегії підтримки, зменшення або посилення емоційного реагування; контролю за емоційними реакціями, щоб визначити їх відповідність, розумність застосування; залучення (активація) емоцій, якщо вони корисні, конструктивні, та відключення, якщо ні; залишатися відкритими для приємних і неприємних переживань, якщо це необхідно, та для інформації, яку вони передають. Отже, визначені виміри 
ЕІ дозволяють вести мову про компетентність людини щодо емоційних переживань, проявів як своїх, так і інших людей.

Саме поняття «компетентність» трактується як широкі професійні знання, ставлення та навички, необхідні для роботи у спеціалізованій галузі чи професії [4]. Виділяють два виміри у трактуваннях компетентностей: специфічний професійний, який передбачає систему знань, умінь, навичок, необхідних для успішної реалізації діяльності; психологічний, що грунтується на поведінці і досліджує внутрішню мотивацію та стратегічні підходи індивідів [4]. Саме другий вимір актуальний у контексті цієї статті. Хоча самоконтроль емоцій та переживань також сприяє успішній реалізації професійних умінь, дій.

Дослідники A. Gonczi, J. Athanasou (2004) класифікують компетентності за трьома групами: компетентності як перелік завдань; компетентності як сукупність атрибутів; компетентності як цілісні або інтегровані відносини [8]. Менеджмент був однією 3 перших галузей, в яких були розроблені моделі компетентностей, які допомагають відбору та навчанню фахівців. Бояціс представив модель компетентностей, що складається 3 різних кластерів: 1. Кластер управління людськими ресурсами (управління груповими процесами, точна самооцінка та позитивне ставлення). 2. Кластер лідерства (включаючи впевненість у собі, концептуалізацію, логічну думку та використання усної презентації). 3. Кластер управління цілями та діями (включаючи орієнтацію на ефективність, діагностику використання концепцій, турбота про вплив та проактивність). 4. Спрямування групи підлеглих (зокрема, використання односторонньої сили, розвиток інших, спонтанність) та об' єктивне сприйняття [2, с. 194]. Бояціс починає свої міркування з поняття ефективного виконання, так само, як це робив Уайт у визначенні компетентності як ефективної взаємодії 3 навколишнім середовищем. Бояціс говорить про досягнення конкретних результатів шляхом конкретних дій, які мають відповідати організаційній політиці, процедурам та умовам [2, с. 12]. Ефективні конкретні дії чи поведінка є перетином компетенцій особистості, вимог роботи та середовища організації [2, с. 13]. Бояціс визначає компетентність як «... основну характеристику осіб, що призводить до ефективного та/або вищого результату в роботі» [2, с. 20-21]. Далі він описує основну характеристику як «мотив, рису, майстерність, аспект власного іміджу чи соціальної ролі, або сукупність знань <..> Мотиви є рушіями поведінки, а ефективність компетентності - одна 3 них. Риси є досить сталими характеристиками особистості, такими як Велика п’ятірка. Я-образ $\epsilon$ результатом компетентності та пов'язаний із самоефективністю. Соціальні ролі - це позиції на ринку праці, що зумовлені певним видом діяльності, передбачають права та обов'язки, що визначають соціальну взаємодію. Компетентність визначає професіоналізм, тому що без компетентності професіонал не зміг би виконати відповідну професійну роль. Компетенції - це вимоги до продуктивності, без яких професіонали не змогли б ефективно працювати у своїх професійних ситуаціях. Знання, вміння та ставлення є складниками компетентності.

Бояціс використав метод п'яти кроків для формування моделі компетентності [2, с. 42]: 1. Визначення критеріїв (йдеться про вибір відповідного виду роботи для визначення продуктивності та збір даних, у результаті чого отримуються дані про ефективність роботи менеджерів). 2. Аналіз (виявлення характеристик у кластерах, які впливають на ефективність, продуктивність за оцінками менеджерів). 3. Інтерв'ю щодо поведінкових проявів (опитування, кодування співбесід за характеристиками, пов'язування їх із даними про результати роботи та перелік підтверджених компетенцій). 4. Тести та заходи (тести для оцінки компетентності та їх співвіднесення 3 даними про результати роботи). 5. Модель компетентності (визначення причинно-наслідкових зв'язків між компетентностями та результатами роботи, що дозволяє перевірити модель компетентності). Така модель, за словами Бояціс, грунтується на ефективності. Однак не у всіх професіях легко знайти взаємозв'язок між компетентністю, видом діяльності (роботою) та продуктивністю, оскільки не у всіх професіях $є$ чіткі критерії ефективності, зокрема у викладацькій діяльності. Наприклад, ефективність одного викладача може залежати від діяльності іншого викладача, який закладав основу знань студентові.

Отже, розглянуті моделі компетентностей не виділяють професійний та психологічний виміри. Такі моделі компетентностей $є$ більш релевантними для моделей менеджменту (лідерства), що грунтуються на цінностях конкуруючого лідерства. Вимоги сучасного світу потребують нових підходів до управління (лідерства). Сучасні теорії лідерства (діадична теорія, теорії харизматичного лідерства, трансформаційного лідерства) відкидають конкуренцію і за основу беруть вплив $[1 ; 11 ; 14]$, ефективність, конструктивність якого 
буде визначатися емоційним інтелектом. У чому сутність трансформаційного, діадичного лідерства? Трансформаційний лідер спрямований на довготривалі стосунки 3 підлеглими, на актуалізацію у них прагнення до досягнень та саморозвитку, трансформацію цілей організаційних у власні, створювач нових шляхів і способів, новатор, здатний до самолідерства та сервант-лідерства (обслуговуючого), який здатний організувати команду на вирішення складних завдань. Успішність взаємодії залежить від якості взаємин, які розвиваються в інтеракціях [1], інграціації (особливий тип впливу однієї людини на іншу за допомогою чарівності, привабливості), харизми. Безперечно, що всі ці процеси складно уявити без такої важливої компетентності, як здатність розуміти власні переживання та інших людей, уміння контролювати емоції та управляти ними. На підтвердження цієї тези є результати дослідження [9], які доводять важливість у структурі професійного профілю менеджерів психофізіологічного та емоційно-вольового потенціалу індивіда (комунікативні здібності, оволодіння своїми почуттями, мотивація тощо) та емоційного інтелекту [14].

Про актуальність емоційного інтелекту у структурі професійного профілю лідерства йдеться у Профілі культури лідерства, що прийнятий в $\mathrm{OOH}$ (Організації об'єднаних націй) [18]. Профіль має три компоненти: цінності (доброчесність, професіоналізм та повага до різноманітності); базові атрибути (пристрасний, мужній, емоційно розумний, скромний, відкритий до нового досвіду, творчий, гнучкий, стійкий), знання, компетенції (здатність аналізувати складні середовища, визначати шляхи впливу у складних середовищах, здатність до спільної творчості, формування довірливих стосунків, сприяти колективним діям, зосереджуватися на успіхах, сприяти трансформаційним змінам, стимулювати інновації, провідні зміни).

Якщо розглядати окреслені компоненти профілю з точки зору його функційності, то $є$ очевидною актуальність високого рівня усвідомлення, рефлексії лідера, що є інтегральною здатністю для ефективного виконання професійної ролі. Проаналізуємо компонент «цінності», який передбачає такі характеристики, як: цілісність, професіоналізм, повага до різноманітності. Така диспозиція, як цілісність, конгруентність, є, безперечно, результатом рефлексії, самоаналізу, завдяки яким відбувається прийняття власної Я-концепції, інтеграції різних аспектів Я. Саме конгруентна особистість здатна підпорядковувати власні інтереси суспільним, груповим, при цьому не зловживати владою чи повноваженнями і брати відповідальність за прийняті рішення в інтересах організації. Професіоналізм, безперечно, $\epsilon$ важливою цінністю, на якій грунтується профіль лідера, яка не обмежується володінням предметом, ефективним виконанням зобов'язань, досягненням результатів, але й, як зазначається у Профілі, передбачає стресостійкість, наполегливість у разі зіткнення зі складними проблемами, мотивування себе 3 позицій професійних, а не особистісних проблем. Саме останні характеристики - стресостійкість та професійне мотивування - певною мірою будуть залежати від здатності розуміти власні переживання, вміти ними вдало керувати, змінювати емоційний стан таким чином, щоб емоції сприяли продуктивності праці, зростанню професійної мотивації. Тому професіоналізм потребує емоційної компетентності створювати емоції як допоміжний засіб для судження та пам'яті, пріоритетне мислення, спрямовувати увагу відповідно до актуальних (теперішніх) переживань. Повага до різноманітності (цінність) передбачає професійну взаємодію із людьми з різним досвідом, точками зору, із повагою, гідністю, розумінням власних упереджень. Забезпечення діяльності лідера у межах такої цінності буде визначатися наявністю у нього здатності до розуміння емоцій, зокрема, здібності розпізнавати культурні відмінності в оцінці емоцій; розуміти, як може відчувати себе людина в майбутньому або за певних умов (афективне прогнозування); розуміти складні емоційні переживання, оцінювати ситуації, які можуть викликати відповідні емоції, визначати причини виникнення та значення, наслідки відповідних емоцій.

Наступний компонент профілю «базові атрибути» передбачає: емоційний інтелект, захопленість справою, мужність, скромність, відкритість до нового досвіду, творчість, гнучкість та стійкість. Ефективний лідер не може мотивувати своїх підлеглих до продуктивної діяльності, якщо він незахоплений справою, якою керує, немає толерантності до невизначеності та впливу умов середовища, гнучкого реагування на зміни умов середовища. Успішність його діяльності буде залежати від здатності відстояти цінності, позиції, ідеї групи, яку очолює, при цьому враховуючи інтереси різних сторін. Безперечно, що у такому випадку лідер повинен ефективно керувати власними емоціями, емоціями інших людей для досягнення бажаного результату, вміти оцінювати стратегії підтримки, зменшення або посилення емоційного реагування. Інакше кажучи, емоційний інтелект є важливим 
атрибутом профілю лідера, який слугує основою, умовою для реалізації інших атрибутів.

Компонент профілю лідера-управлінця «знання і компетенції» передбачає здатність до системного мислення, фокусування, визначення шляхів впливу у складних середовищах (нові умови, вимоги, кризові періоди) та ключових результатів, здатність до співпраці, яка грунтується на довірі, створення умов для колективних дій, здатність до проведення трансформаційних змін, сприяння інноваціям. Корелятами здатності до системного мислення визначають пошук знань та розумінь, отриманих із різних джерел, розуміння різних точок зору та упереджень, уміння оперувати суперечливою інформацією; здатності аналізувати і розуміти основні організаційні принципи, моделі, відносини, зв'язки, залежності та взаємодії між різними елементами, компонентами середовища; виявляти, інтерпретувати нові тенденції, можливі ризики, розуміти вплив динамічних процесів (політичних, економічних, гендерних, соціальних) у середовищі, позитивні та негативні наслідки від них. Постійно перевіряти дані, припущення та уявлення у контексті змін обставин. Корелятами компетенції визначення шляхів впливу у складних середовищах визначають здатність до стратегічного позиціонування себе та організації як значущої ланки середовища, як спроможності реалізовувати політику дії у багатопрофільних та політично складних середовищах; здатність бачити чутливі питання, проблеми та їхні наслідки, виявляти можливості для трансформаційних змін і впливів в організації, приймати швидкі рішення; здійснювати моніторинг та обмін інформацією із зацікавленими партнерами 3 метою виявлення актуальних проблем чи прогресу для вироблення подальших стратегій; здатність спрямовувати підлеглих на досягнення результату, що перевершує очікування, та спрямовувати на досягнення нових цілей.

Корелятами компетенції до співпраці, яка грунтується на довірі, визначено здатність до налагодження комунікації, взаємодії із різними групами людей (різних галузей, організацій, статі, поколінь, культурних, соціально-економічних відмінностей), зокрема, маргіналізованими групами шляхом розуміння їхніх потреб, пріоритетів, інтересів, цінностей; здатність створити психологічно безпечне середовище, в якому зацікавлені сторони можуть без остраху порушувати будь-які питання, демонструвати послідовність, надійність, дотримуватися взятих на себе зобов'язань. Сприяння колективній співпраці визначається за корелятами: здатність залучати зацікавлені сторони до співавторства у виробленні спільного бачення, цілей, формувати уявлення про сприяння колективним результатам досягнення власних цілей; здатність спільно аналізувати проблеми і приймати рішення. Сприяння інноваціям та змінам визначається за поведінковими корелятами: здатність критично оцінювати та переглядати звичні способи ведення справ, підтримує експериментування, прототипування, інвестиції в інклюзивні інновації, проявляє обізнаність і захоплення інноваційністю, творчістю інших, підтримуючи їх від концепції впровадження ідеї до успіху, заохочує досягнення результатів через навчання на помилках та невдачах; керує трансформаційними змінами та створює середовище, яке адаптовується до них; сприяє передбаченню та попередженню стратегічних ризиків, забезпечує бачення змін, встановлює зв'язки між ними, постійно і послідовно стимулює зміни, моделює бажані результати прогресу; модерує ставлення до змін середовища як у бізнес-процесах, так і людей з метою адаптації до трансформацій. Отже, аналіз корелятів компонента «знання та компетенції» свідчить про необхідність володіння лідером-управлінцем здатностями аналізу, прогнозування, моделювання, проєктування бізнес-процесів, у які включені люди із певним досвідом реагування на ситуації, тому важливою умовою реалізації цих здатностей $є$ наявність емоційного інтелекту, зокрема, володіння високим рівнем розуміння, управління емоціями як своїми, так і інших людей.

Висновки. Таким чином, проведений теоретичний аналіз визначення ролі емоційного інтелекту у структурі професійного профілю менеджера дозволяє зробити низку висновків. Вимоги сучасного світу потребують нових підходів до управління, які відкидають цінності конкурентного лідерства та за основу беруть взаємодію та вплив, ефективність, конструктивність яких буде визначатися емоційним інтелектом. Успішність взаємодії залежить від якості взаємин, які розвиваються в інтеракціях. Якість взаємин визначається ЕІ. Емоційний інтелект розглядається як здатність обмірковувати емоції та інформацію, пов'язану з ними, і використовувати їх для підсилення мисленнєвого процесу. Емоційний інтелект має чотири виміри здібностей: сприйняття емоцій, сприяння процесам мислення, використання емоцій, розуміння емоцій та управління емоціями, які виконують функцію компетентностей людини щодо емоційних переживань, проявів як своїх, 
так і інших людей. Кожен із вимірів ЕІ є умовою реалізації компонентів професійного профілю менеджерів. Характеристики компонента «цінності» пов'язані із такими вимірами EI, як фасилітація та розуміння емоцій; компонента «базові атрибути» - фасилітація, управління, розуміння емоцій; компонента «знання i компетенції» сприймання, управніння, розуміння емоцій, що дозволяє робити попередні припущення про емоційний інтелект як інтегральну характеристику у професійному профілі менеджера, що $\epsilon$ необхідною умовою ефективної діяльності лідера.

\section{Список літератури:}

1. Заграй Л.Д., Федорук О.Ф. Психосемантичні конструкції лідерства у свідомості молоді: гендерний вимір. Психологія та сочіальна робота. Одеса : «Астропринт». Випуск 1(51). 2020. С. 84-100.

2. Boyatzis R.E., Goleman D., \& Rhee K. Clustering competence in emotional intelligence: Insights from the Emotional Competence Inventory (ECI). / In Bar-On, R. \& J.D. Parker (Ed's.), Handbook of Emotional Intelligence. San Francisco : Jossey-Bass. 1999.

3. Goleman D. (2005). Emotional Intelligence. 10th ed. New York : Bantam Books. 2005.

4. Guerrero, Dante, De los Ríos Ignacio. Professional competences: a classification of international. ProcediaSocial and Behavioral Sciences. 2012. 46. 1290-1296.

5. Jensen S., Kohn C., Rilea S., Hannon R., \& Howells G. Emotional intelligence: A literature review. University of the Pacific, Department of Psychology, Stockton, CA. 2007, July 15. URL: http://web.pacific.edu/Documents/ library/acrobat/EI\%20Lit\%20Review\%202007\%20Final.pdf.

6. Jordan P.J., \& Troth A.C. Managing emotions during team problem solving: Emotional Intelligence and conflict resolution. In Human Performance, 2004. 17(2), 195-218.

7. Locke E.A. Why emotional intelligence is an invalid concept. Journal of Organizational Behavior, 2005. $26,425-431$.

8. Mayer John D., Caruso David R., Salovey Peter. The Ability Model of Emotional Intelligence: Principles and Updates. Emotion Review. First Published August 18, 2016, pp. 290-300.

9. Orekhova T., Orekhov V., \& Karandina I. HR Manager: New Innovative Requirements for His/Her Expertise. Leadership and Management. 2015. 2(3), 191-208.

10. Pappas B. The logic of emotion - Emotional Development and Emotional Intelligence. Athens : Eight publications. 2013.

11. Polston-Murdoch L. An Investigation of Path-Goal Theory, Relationship of Leadership Style SupervisorRelated Commitment, and Gender. Emerging Leadership Journeys. 2013. Vol. 6. Iss. 1. P. 13-44.

12. Reus T.H. \& Liu, Y. "Rhyme and Reason: Emotional Capability and The Performance of KnowledgeIntensive Work Groups". Human Performance, 2004. Vol. 17, pp. 245-266.

13. Rosete D., Ciarrochi J. Emotional intelligence and its relationship to workplace performance of leadership effectiveness. Leadersh. Organ. Dev. J. 2005. 26: 388-99.

14. Rubin R.S., Munz D.C., Bommer W.H. Leading from within: the effects of emotion recognition and personality on transformational leadership behavior. Acad. Manage. J. 2005. 48: 845-58.

15. Sala F. "Linking Emotional Intelligence and Performance at Work : Current Research Evidence with Individuals and Groups". Mahwah, NJ, USA : Lawrence Erlbaum Associates, Incorporated, 2005. 292 p.

16. Salovey Peter \& Mayer John D. Emotional Intelligence. Imagination, Cognition \& Personality, 9 (3) 1989; 1990, 185-211.

17. Sy T., Tram S., and O'Hara L.A. Relation of employee and manger emotional intelligence to job satisfaction and performance. In Journal of Vocational Behavior, 68, 461-473. 2006. URL: http://www.emeraldinsight.com.

18. The RC Leadership Profile was developed by the UNSDG Task Force on RC Talent Management. December 2020. URL: https://interagencystandingcommittee.org/resident-coordinatorhumanitarian-cordinatortalent-pipeline.

\section{Zahrai L.D. EMOTIONAL INTELLIGENCE AS A COMPONENT OF PROFESSIONAL COMPETENCE OF A MANAGER}

The purpose of the article is to determine the key dimensions of emotional intelligence in the structure of professional competence of the manager (leader). Objectives of the article: to make a theoretical analysis of the concepts of emotional intelligence in the context of professional competence; determine the dimensions of emotional intelligence in the structure of professional competence of the manager. Three groups of studies of emotional intelligence have been identified: EI is considered as an ability that is related to the ability to understand and control emotions; EI is considered a personal characteristic; EI is considered as a combination of these models - mixed models. Emotional intelligence is interpreted as the ability to reasonably reflect on emotions and information related to emotions, and use emotions to enhance the thought process. 
Emotional intelligence is interpreted as the ability to reasonably ponder on emotions and information related to emotions, and use emotions to enhance the thought process. Leadership models are outlined: based on competition values; based on the values of interaction, influence. The relevance of emotional intelligence in the structure of the professional profile of leadership is proved. Four dimensions of abilities are identified: perception of emotions, facilitation of thought processes, use of emotions, understanding of emotions and emotion management, which perform the function of human competencies in relation to emotional experiences, manifestations of oneself and other people. EI dimensions are related to the components of the professional profile of managers. The Profile has three components: values; basic attributes; knowledge, competencies. The characteristics of the value component are related to EI dimensions such as facilitation and understanding of emotions; component "basic attributes" - facilitation, management, understanding of emotions; component "knowledge and competence" - perception, management, understanding of emotions, which allows to make preliminary assumptions about emotional intelligence as an integral characteristic in the professional profile of the manager, which is a necessary condition for effective leadership.

Key words: emotional intelligence, competence, professional profile, manager, leadership. 